\title{
Optimization of rice straw pretreatment with 1-ethyl-3- methylimidazolium acetate by the response surface method
}

\author{
Helena Poy ${ }^{1} \cdot$ Estela Lladosa $^{1}$ (D) $\cdot$ Carmen Gabaldón $^{1}$ (D) $\cdot$ Sonia Loras ${ }^{1}$ (D)
}

Received: 23 July 2021 / Revised: 26 October 2021 / Accepted: 22 November 2021

(c) The Author(s) 2021

\begin{abstract}
Rice straw (RS) is a promising feedstock for transformation into biofuels and bioproducts due to its high sugar content and worldwide availability. However, a pretreatment step is necessary in order to disrupt the RS complex lignocellulosic matrix. The aim of this work was to study RS pretreatment with the ionic liquid 1-ethyl-3-methylimidazolium acetate ([Emim] [OAc]) to maximize the enzymatic hydrolysis yield. For this purpose, a response surface method (RSM) based on a central composite design $(\mathrm{CCD})$ was used, with temperature $\left(53-137^{\circ} \mathrm{C}\right)$, time $(0.3-6.2 \mathrm{~h})$, and solid loading (3.3-11.7\% dry weight) as process variables. The analysis of variance (ANOVA) results suggested that temperature was the most significant factor affecting the fermentable sugar yield of [Emim][OAc]-pretreated RS samples. The selected conditions for this pretreatment were $120{ }^{\circ} \mathrm{C}, 5 \mathrm{~h}$, and $5 \%(\mathrm{w} / \mathrm{w})$, obtaining $29.8 \mathrm{~g} / \mathrm{L}$ of potentially fermentable sugars. In these conditions, maximum delignification was achieved (64.9\%) as well as maximum reduction of the crystallinity index (62.2\%), as determined by X-ray diffraction analysis. Fourier-transform infrared spectroscopy (FT-IR) and scanning electron microscopy (SEM) analysis were used to confirm the RS amorphous structure after the pretreatment with [Emim][OAc] and showed that it had a more disordered and accessible structure.
\end{abstract}

Keywords Central composite design · Enzymatic hydrolysis · Ionic liquids · Pretreatment $\cdot$ Rice straw $\cdot$ 1-Ethyl-3methylimidazolium acetate

\section{Introduction}

The depletion of fossil fuel resources and the associated environmental pollutions such as climate change and greenhouse gas emissions have increased interest in the search for sustainable and renewable sources of energy [1]. Bioalcohols can play a vital role in reducing transportation sector emissions [2], highlighting biobutanol produced by biotechnological processes as an advanced biofuel because of its superior properties such as high energy density and its similarity to gasoline [3]. Lignocellulosic biomass consisting of sugars in the form of cellulose and hemicellulose polysaccharides linked with a polyphenolic macromolecule

Sonia Loras

Sonia.loras@uv.es

1 Department of Chemical Engineering, Universitat de València, Av. De la Universitat S/N, 46100 Burjassot, Valencia, Spain known as lignin is the most renewable source on earth. It is considered a promising feedstock for producing biofuels and bioproducts owing to its availability, low cost, carbon neutrality, and high fermentable sugar content $[4,5]$. Rice straw (RS) is a good candidate for this resource, with an annual production of 600-900 million tons worldwide. RS is mainly composed of cellulose (32-47\%), hemicellulose (19-27\%), and lignin (5-29\%) and other minority compounds such as ash and silica (7.8-20.3\%) and extractives (16.1-19.3\%) [6]. Due to its recalcitrance, a pretreatment step is crucial to disrupt the complex structure between polysaccharides and lignin, thus increasing the surface area and accessibility to enzymes [7]. Several pretreatment methods, viz., physical, chemical, and biological processes, have been developed to enhance the disruption of lignocellulosic materials [8]. However, most of these methods have certain disadvantages, such as severe operating conditions, high energy requirements, high toxicity, formation of inhibitory compounds, and loss of fermentable sugar content [9]. 
Currently, the use of ionic liquids (ILs) in pretreatment has received increased attention due to their green properties, besides the ability to dissolve carbohydrates and lignin [10]. ILs are salts consisting entirely of ions with low melting points and special properties including low or negligible vapor pressure, high chemical and thermal stability, non-flammability, and recyclability [11]. Their strong hydrogen bonding coordination promotes the alteration of the involved network among carbohydrates and lignin allowing their separation, alongside the minimum formation of degradation products during the process [12]. These solvents are also effective for dissolving cellulose by breaking the hydrogen bonds between its molecular chains through the interaction with cellulose's hydroxyl groups [13]. Dissolved cellulose can be easily regenerated by the addition of an anti-solvent such as water or ethanol [14], exhibiting significantly reduced crystallinity after precipitation [15]. Among the variety of ILs used in pretreatment, 1-ethyl3-methylimidazolium acetate $([\mathrm{Emim}][\mathrm{OAc}])$ is recognized as one of the best solvents because it can efficiently dissolve lignocellulosic compounds, besides its biodegradability and relative non-toxicity and non-corrosivity $[16,17]$. A broad variety of lignocellulosic substrates have been successfully pretreated using [Emim][OAc], such as Guinea grass [17], Agave tequilana bagasse [18], aspen wood [19], and poplar and switchgrass [20]. Haykir and Bakir [21] demonstrated [Emim] [OAc] was better than alkali pretreatment in enhancing enzymatic hydrolysis of pretreated cotton stalks regardless of the substrate loading used, mainly due to its ability to disrupt the crystalline structure.

A useful tool for the optimization of processing conditions is the central composite design (CCD) based on the response surface method (RSM), commonly used to fit empirical second-order polynomial models [22, 23]. Although CCD based on RSM could be used to optimize the process variables affecting pretreatment of biomass with ILs, such as temperature, time, solid loading, and IL concentration [23-27], this methodology has some drawbacks, such as predicting nonfeasible responses. In this context, using physicochemical techniques such as Fourier transform infrared spectroscopy (FT-IR), X-Ray diffraction (XRD), and scanning electron microscopy (SEM) may unravel the biomass during IL pretreatment. Structural techniques can be very helpful when preselecting multiple optimum parameters. Combination of structural techniques with CCD methodology could improve the study of IL pretreatment by adding information regarding molecular mechanism in the selection of the preferable conditions, leveraging the advantages of both techniques: the multiple analysis of several variables affecting the process and their interaction with a reduced number of experiments, alongside with a selection of the preferred conditions based too in a better understanding of the molecular mechanism of IL pretreatment in biomass.
The aim of this work was to study the [Emim][OAc] pretreatment of RS by using RSM in combination with structural techniques. For this purpose, CCD was used to analyze the effect of three processing parameters (temperature, time, and solid loading) on the enzymatic hydrolysis yield of [Emim][OAc]-pretreated samples and to develop a mathematical model able to adequately predict the process response variable from given input values. The optimal conditions were selected by combining CCD with structural techniques, which are key factors in elucidating the effect of IL on RS. The novelty of this work consisted in the development of a useful and relative quick study of the pretreatment of RS which allowed the study of pretreatment of RS with IL using a reduced number of experiments, combining mathematical methods (CCD), analytical methods, and biochemical process (saccharification).

\section{Materials and methods}

\subsection{Raw materials and chemicals}

RS was acquired from the Albufera Natural Park located near Valencia (Spain). After being dried in air, RS was milled and sieved to a particle size between 100 and $500 \mu \mathrm{m}$, and then, it was stored in sealed containers at $4{ }^{\circ} \mathrm{C}$. Before use, it was dried at $45^{\circ} \mathrm{C}$ for $12 \mathrm{~h}$. [Emim] [OAc] ionic liquid (95\% purity by weight) was purchased from IoLiTec (Germany) and used without further purification. The cellulase enzyme blend Cellic ${ }^{\circ}$ CTec2 was purchased from Novozymes (Denmark), and its cellulase activity (189 FPU/mL) was determined according to the protocol of the National Renewable Energy Laboratory (NREL) [28]. All chemicals needed for RS characterization such as sulfuric acid (98\% purity by weight) and ethanol (96\% purity by weight) were purchased from Sigma-Aldrich (USA).

\subsection{Ionic liquid pretreatment}

Pretreatment was carried out by mixing RS and [Emim] [OAc] at different solid loadings in $60 \mathrm{~mL}$ Ace Glass pressure tubes (Model 8648-137, Ace Glass, USA). A total $3.30 \mathrm{~g}$ of RS was used in each experiment with the corresponding quantity of IL. The pressure tube was then placed in an orbital shaker (Rotaterm 300,045, Selecta, Spain) and heated to the desired temperature $\left(52-137^{\circ} \mathrm{C}\right)$ for a certain time $(0.3-6.2 \mathrm{~h})$, with an agitation rate of $100 \mathrm{rpm}$. At the end of the pretreatment, pressure tubes were submerged in a glass containing cool water to stop the extraction, and $10 \mathrm{~mL}$ of deionized water was added to the RS-IL mixture to regenerate the dissolved polysaccharides. The biomass slurry was vigorously washed with deionized water, and the solid fraction was separated by vacuum filtration. The 
remaining IL was removed by washing the filters, and the filtrate solids were dried at $105{ }^{\circ} \mathrm{C}$ and stored at $4{ }^{\circ} \mathrm{C}$ in sealed containers. The absence of [Emim][OAc] in solid pretreated samples was confirmed by Fourier transform infrared spectroscopy.

\subsection{Enzymatic hydrolysis}

Untreated and [Emim] $[\mathrm{OAc}]-$ pretreated RS samples were subjected to enzymatic hydrolysis in 100-mL conical flasks on a shaking incubator (Model G25, New Brunswick Scientific, USA) using Cellic $\mathrm{CTec} 2$ commercial enzyme blend. A biomass loading of 5\% (w/v) and an enzyme dosage of $20 \mathrm{FPU} / \mathrm{g}$ dry biomass were used. All the hydrolysis assays were performed with $50 \mathrm{mM}$ sodium acetate buffer (pH 5.0) at $50{ }^{\circ} \mathrm{C}$ and $150 \mathrm{rpm}$ for $72 \mathrm{~h}$. After enzymatic hydrolysis, the reaction mixture was centrifuged (Centrifuge 5804, Eppendorf, Germany) at $4000 \mathrm{rpm}$ for $6 \mathrm{~min}$ and then vacuum filtered. The hydrolysate liquid fraction was analyzed for reducing sugars (cellobiose, glucose, xylose, and arabinose) and inhibitory compounds (formic acid, acetic acid, levulinic acid, 5-HMF, and furfural) by high-performance liquid chromatography (HPLC). Fermentable sugar yield (FSY) was calculated as follows:
Ash losses $(\%)=100-\frac{\% \text { Ash in pretreated RS } \cdot \% \text { Solid recovery }}{\% \text { Ash in untreated RS }}$

\subsubsection{Structural analysis}

FT-IR analyses of untreated and pretreated samples were carried out to determine chemical changes in the RS structure. These analyses were conducted in an ATR-FT-IR spectrometer (ATR Agilent Cary 630 FT-IR spectrometer, Agilent, USA). Sample spectra were obtained in duplicate using 64 scans per sample over the range of $400-4000 \mathrm{~cm}^{-1}$ with a spectral resolution of $2 \mathrm{~cm}^{-1}$. The effects of pretreatment on the RS morphology were analyzed by scanning electron microscopy (S-4800, Hitachi, Japan) operating at an acceleration voltage of $10 \mathrm{kV}$. Untreated and [Emim][OAc]pretreated RS samples were sputter-coated with gold palladium before SEM analysis. Surface morphology images of some RS samples were acquired at a magnification of $35 \times$, $180 \times$, and $500 \times$. Changes in crystallinity after pretreatment were analyzed by X-ray powder diffractometry (XRD). XRD measurements were performed on a Bruker D8 Advance

Fermentable sugar yield $(\%)=\frac{\text { Reducing sugars released }\left(\mathrm{g} \cdot L^{-1}\right) \times V_{\text {hydrolysis }}(\mathrm{L})}{\text { Mass of RS hydrolyzed }(\mathrm{g}) \times \text { Total sugars in pretreated RS }(\%)} \cdot 100$

\subsection{Characterization of untreated and pretreated rice straw}

\subsubsection{Chemical characterization}

The chemical composition of untreated and pretreated RS was determined using NREL protocols [29-33]. For lignin determination, the solid fraction was calcinated (CWF1100, Carbolite Gero LTD, UK) to quantify acid insoluble lignin (AIL), while acid soluble lignin (ASL) was measured by UV-Vis spectrophotometry at 205 nm (SpectroFlex 6600, WTW, Germany). Sugars were analyzed by HPLC (Agilent 1100 Series, Agilent Technologies, USA) equipped with a RID detector and an Aminex HPX-87H column (Bio-Rad, Richmond, CA, USA) at $35^{\circ} \mathrm{C}$ using $5 \mathrm{mM}$ sulfuric acid as mobile phase at a flow rate of $0.6 \mathrm{~mL} / \mathrm{min}$. The inhibitory content of hydrolyzed samples was also determined by HPLC using a DAD detector. Acetic, levulinic, and formic acids were analyzed at $210 \mathrm{~nm}$, while furfural and 5-HMF were analyzed at $280 \mathrm{~nm}$. The pretreatment efficiency was assessed in terms of the following:

Sugar recovery $(\%)=\frac{\% \text { Sugar in pretreated RS } \cdot \% \text { Solid recovery }}{\% \text { Sugar in untreated RS }}$
A25 X-ray diffractometer (Bruker, USA) equipped with $\mathrm{Cu}$ radiation $(\lambda=1.5406 \dot{A})$. Samples were scanned over the angular range of $5-60^{\circ}$, with a step size of $0.02^{\circ}$ and step time of $1 \mathrm{~s}$. The crystallinity index (CrI) of the samples was calculated by the peak intensity method [34] as

$\mathrm{CrI}=\left(\frac{\mathrm{I}_{002}-\mathrm{I}_{\mathrm{am}}}{\mathrm{I}_{002}}\right) \cdot 100$

where $I_{002}$ is the maximum diffraction peak intensity of plane 002 (at around $2 \theta=22.1^{\circ}$ ) and $I_{\mathrm{am}}$ is the amorphous peak at around $2 \theta=18.7^{\circ}$.

\subsection{Experimental design and statistical analysis}

A response surface method based on a central composite design was applied to study the effect of pretreatment conditions (temperature, time, and solid loading) on the response variable selected: fermentable sugar yield. For this purpose, the commercial software Minitab 19.1 (Minitab Inc., USA) was used. The experimental design included five levels of the three independent variables for a total of twenty runs

Delignification $(\%)=100-\frac{\% \text { Lignin in pretreated RS } \cdot \% \text { Solid recovery }}{\% \text { Lignin in untreated RS }}$ 
with six replicates at the central point (Table 1). The central values of the parameters studied were based in the arithmetical media between the values of the high and low factors fixed in the design of experiments. High and low factors of temperature and time were selected considering its potential scale-up. Regarding solid loading, previous experiments were carried out in order to ensure a good wettability and thus a well mass transfer between [Emim][OAc] and RS. The experimental results were fitted into a second-order polynomial regression model as shown in Eq. (7):

$y=\beta_{0}+\sum_{i=1}^{3} \beta_{i} x_{i}+\sum_{i=1}^{3} \beta_{i i} x_{i}^{2}+\sum_{i=1}^{3} \sum_{j=i+1}^{3} \beta_{i j} x_{i} x_{j}$

where $y$ is the response variable (FSY), $x_{\mathrm{i}}$ is the independent variable (temperature, time, and solid loading), $\beta_{0}$ is the constant coefficient, $\beta_{\mathrm{i}}$ is the linear coefficient, $\beta_{\mathrm{ii}}$ is the quadratic coefficient, and $\beta_{\mathrm{ij}}$ is the $i j$ interaction coefficient.

The evaluation of each coefficient of the model was statistically processed by analysis of variance (ANOVA) at the significance level of $p=0.05$. Assessment of the model was based on the R-squared value $\left(R^{2}\right)$ and model $p$ value. Its validation was carried out by four replicates of the experiment that achieve the best conditions for [Emim][OAc] pretreatment of RS.

\section{Results and discussion}

\subsection{Effects of pretreatment on rice straw recovery and composition}

The chemical composition and solid recovery of untreated and pretreated RS, as well as sugar recoveries, delignification, and ash losses are summarized in Table 2. Untreated RS contained $35.8 \pm 2.1 \%$ glucan, $14.8 \pm 1.6 \%$ xylan, $2.7 \pm 0.4 \%$ arabinan, $14.3 \pm 0.3 \%$ lignin, $13.2 \pm 2.1 \%$ extractives, $16.7 \pm 0.1 \%$ ashes, and $1.0 \pm 0.1 \%$ acetyl groups $(w / w)$. Compared to other RS batches reported elsewhere [4, 35], the RS of this study showed a greater susceptibility for its sugar exploitation due its lower lignin content, which is known to increase the recalcitrance of lignocellulosic material hindering accessibility to enzymes. After pretreatment, all the RS samples showed mass losses due to the capacity of [Emim] [OAc] to extract biomass components. Despite the loss of material, particularly sugars, extensive washing was required, as any remaining IL could deactivate enzymes and inhibit microorganisms during the enzymatic hydrolysis and fermentation steps [36]. The percentage of recovered solids varied from 62.9 to $95.2 \%$. Generally, solid recovery decreased with increases in temperature and time, also with decreases in solid loading, although temperature had a stronger effect. At higher temperatures, the recovery of biomass components decreased, but biomass dissolution and swelling increased [24]. Likewise, significant amounts of sugars were lost after pretreating RS with [Emim][OAc], although the sugar content had been enriched in some pretreated solids (runs 2 and 7). Glucan recovery after pretreatment varied in the range from 57.6 to $79.5 \%$, while xylan and arabinan recovery varied between $54.8 \%$ to $100 \%$ and $57.9 \%$ to $89.6 \%$, respectively. Although these values are strongly influenced by temperature as solid recovery, a fraction of sugars was lost in the water washing step due to the weaker bond between cellulose and hemicellulose. Li et al. [37] studied the effect of washing [Emim] [OAc]-pretreated switchgrass in sugar losses carrying out seven different successive washes, showing that sugar losses increased with the number of washes due to its loss of bonding with the biomass structure.

Lignin is the main obstacle to enzymatic hydrolysis, since it acts as a barrier against enzymatic attack on carbohydrates, giving resistance and rigidity to the lignocelullosic structure [38]. Delignification after [Emim][OAc] pretreatment varied in the range from 0.8 to $64.9 \%$, increasing with temperature as a result of better lignin dissolution. At low temperatures, delignification was insignificant, achieving only $0.8 \%$ of lignin removal for the experiment at $53{ }^{\circ} \mathrm{C}$ (Run 12). The maximum delignification $(64.9 \%)$ was reached at $120{ }^{\circ} \mathrm{C}$ for $5 \mathrm{~h}$ with 5\% (w/w) solid loading (Run 7). Higher temperatures usually accelerate lignin solubilization, as previously reported [39, 40]. Weerachanchai et al. [41] also proved the suitability of [Emim][OAc] as delignificating solvent for rice straw, obtaining a similar maximum delignification of $63 \%$ at $120{ }^{\circ} \mathrm{C}$ with $5 \%(\mathrm{w} / \mathrm{w}$ ) of solid loading, but for $24 \mathrm{~h}$ instead of the $5 \mathrm{~h}$ employed in this work. Fockink et al. [42] studied the best conditions to delignificate cotton residues with
Table 1 Levels of the pretreatment condition variables tested in the central composite design (CCD)

\begin{tabular}{llllllll}
\hline Process parameters & Coding & Unit & \multicolumn{2}{l}{ Levels } & & & \\
\cline { 4 - 7 } & & & $-\alpha^{*}$ & -1 & 0 & +1 & $+\alpha$ \\
\hline Temperature & $\mathrm{A}$ & ${ }^{\circ} \mathrm{C}$ & 53.0 & 70.0 & 95.0 & 120.0 & 137.0 \\
Time & $\mathrm{B}$ & Hours & 0.3 & 1.5 & 3.3 & 5.0 & 6.2 \\
Solid loading & $\mathrm{C}$ & $\%(\mathrm{w} / \mathrm{w})$ & 3.3 & 5.0 & 7.5 & 10.0 & 11.7 \\
\hline
\end{tabular}

$\alpha^{*}$ (axial distance) $=\sqrt[4]{\mathrm{N}}$, where $N$ is the number of experiments of the factorial design. In this case, the value of $\alpha$ was 1.6818 


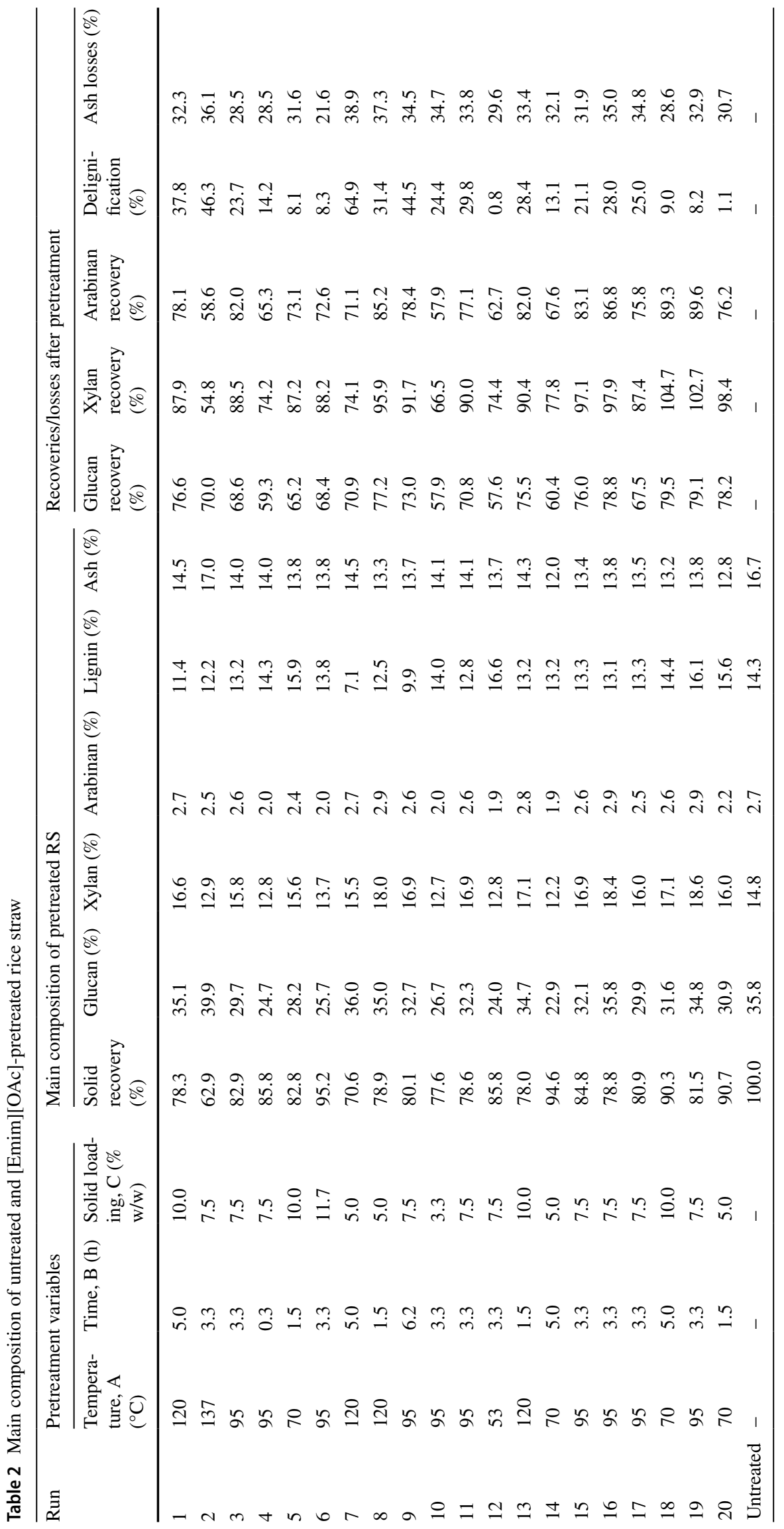


[Emim][OAc], yielding a similar degree of delignification $(62.9 \%)$ but requiring a high temperature $\left(160^{\circ} \mathrm{C}\right)$ with a 3-h reaction by using $10 \%(\mathrm{w} / \mathrm{w})$ solid loading. Odorico et al. [17] obtained a lower delignification degree (20.5\%) during pretreatment of Guinea grass with [Emim] [OAc] at $157^{\circ} \mathrm{C}$, $0.5 \mathrm{~h}$, and $14 \%(\mathrm{w} / \mathrm{w})$ solid loading, which could have been directly influenced by the higher solid loading used, thus negatively impacting the solid-liquid mass transfer.

Ash removal is important since silica, the main component of RS ash, like lignin, blocks cellulitic enzymes. Silica can adsorb cellulases by electrostatic interactions and/or hydrogen bonding, reducing the number of active sites on the cellulase surface, thus requiring a higher enzyme dosage, which raises operating costs [43, 44]. In this study, ash losses varied in the range between 30 and $40 \%$, with higher values achieved at higher temperatures. However, pretreated RS samples still had a significant amount of ash, and its impact was evaluated in the enzymatic hydrolysis stage.

The absence of [Emim][OAc] was also confirmed by analyzing acetic acid content in pretreated samples. In all cases, a decrease in acetyl groups in rice straw after [Emim] [OAc] pretreatment was achieved, varying in the range of $1-60 \%$. However, no clear tendency was observed regarding acetic acid mass balance, so these mass balance do not provide any type of information except the check of absence of acetate ionic liquid in pretreated samples, which was primordial in order to avoid inhibitory interferences promoted by [Emim] [OAc].

\subsection{Effects of pretreatment on enzymatic hydrolysis}

Untreated and [Emim][OAc]-pretreated RS samples were subjected to enzymatic hydrolysis, and results are summarized in Table 3. Without pretreatment, fermentable sugar yield of RS was only $19 \%$, which corresponds to $22.7 \%$, $10.1 \%$, and $7.0 \%$ of glucose, xylose, and arabinose yield, respectively. Saccharification yield after [Emim][OAc] pretreatment was improved in all the cases analyzed, varying in the 30.7-98.3\% range. Generally, hydrolysis yield increases with temperature as a result of a more open and accessible structure. Similar patterns were observed for glucose and hemicelluloses digestibilities; however, higher values were obtained for glucose yields since the enzyme complex used contains mostly cellulase-type enzymes. The maximum sugar yield obtained was $98.3 \%\left(120^{\circ} \mathrm{C}, 5 \mathrm{~h}, 5 \%(w / \mathrm{w})\right.$, run 7) corresponding to $29.8 \mathrm{~g} / \mathrm{L}$ of potentially fermentable sugars. In this run, the cellulose fraction was totally hydrolyzed, indicating the excellent susceptibility of RS to enzymatic attack after [Emim] $[\mathrm{OAc}]$ pretreatment under these conditions. These results were even better than those reported by Poornejad et al. [45] by pretreating rice straw with [Emim] [OAc] at $120^{\circ} \mathrm{C}$ for $5 \mathrm{~h}$ at $5 \%(\mathrm{w} / \mathrm{w})$ solid loading, obtaining glucose yields up to $90 \%$ after enzymatic hydrolysis.
On the other hand, the lowest saccharification yield (31\%) was obtained for run $20\left(70{ }^{\circ} \mathrm{C}, 1.5 \mathrm{~h}, 5 \%(\mathrm{w} / \mathrm{w})\right)$, in which the combination of the low temperature and time was insufficient to deconstruct the RS structure. The enzymatic attack was thus severely limited, and enzymatic hydrolysis values were close to those obtained with untreated RS (19\%). Overall, sugar recovery accounts for the joint evaluation of pretreatment and enzymatic hydrolysis steps, as the loss of material involved is considered for its calculation (Table 3 ). The same trend was found as for fermentable sugar yield, obtaining the highest overall sugar recovery $(70.6 \%)$ in run 7 $\left(120^{\circ} \mathrm{C}, 5 \mathrm{~h}, 5 \%(\mathrm{w} / \mathrm{w})\right)$. Therefore, these conditions can be considered the best exploitation of raw material as regards both from the overall and enzymatic hydrolysis processes.

Inhibitory content after enzymatic hydrolysis was evaluated by HPLC. Levulinic acid and furfural were not detected in any samples, while 5-HMF was only detected in some samples (runs $2,7,9$, and 11$)$ at very low concentrations $(<3 \mathrm{mg} / \mathrm{L})$. These values are favorable for $\mathrm{ABE}$ fermentation, since the reported inhibitory concentrations of furfural and 5-HMF were 0.3 and $0.6 \mathrm{~g} / \mathrm{L}$, respectively [46]. Formic acid was detected in all samples at very low concentrations $(0.07-1.13 \mathrm{~g} / \mathrm{L})$, while inhibitory levels were reported to be greater than $0.5 \mathrm{~g} / \mathrm{L}$ [47]. Acetic acid was the principal sugar degradation product obtained after enzymatic hydrolysis of pretreated samples, promoted by the hydrolysis of acetyl groups of hemicelluloses. Acetic acid concentrations varied in the range between 2.3 and $4.15 \mathrm{~g} / \mathrm{L}$, typical concentration values found in enzymatic hydrolysis studies of pretreated rice straw [48]. Wang et al. [49] demonstrated that an acetic acid concentration of $90 \mathrm{mM}(5.4 \mathrm{~g} / \mathrm{L})$ had no influence on ABE fermentation by Clostridium acetobutylicum DSM 1731. In fact, it has been reported that acetic acid concentrations above $3 \mathrm{~g} / \mathrm{L}$ can improve ABE production by Clostridium beijerinckii DSM 6422 [50]. IL pretreatment produces limited quantities of inhibitors, although minor amounts of IL in pretreated samples are potentially toxic to enzymes and microorganisms [51]. Ninomiya et al. [52] proved that a concentration of $16 \%$ [Emim] [OAc] $(\mathrm{w} / \mathrm{w})$ could reduce the activity of Cellic ${ }^{\circledR}$ CTec 2 by $50 \%$, while only an [Emim][OAc] concentration of $0.6 \%(\mathrm{w} / \mathrm{w})$ was sufficient to reduce the relative yeast growth in a culture with Saccharomyces cerevisiae by $50 \%$. The high fermentable sugar yields achieved in our study $(>85 \%$ in runs 1,2, 7, and 10) confirmed the proper washing procedure during $[\mathrm{Emim}][\mathrm{OAc}]$ pretreatment despite the loss of sugars in pretreated samples.

\subsection{Statistical analysis of response surfaces}

The influence of temperature, time, and solid loading on fermentable sugar yield was studied by RSM based on a CCD. The experimental data shown in Table 3 were used to determine the regression coefficients of the second-order polynomial model (Eq. 7) and the model predicted values for the variable response as follows: 


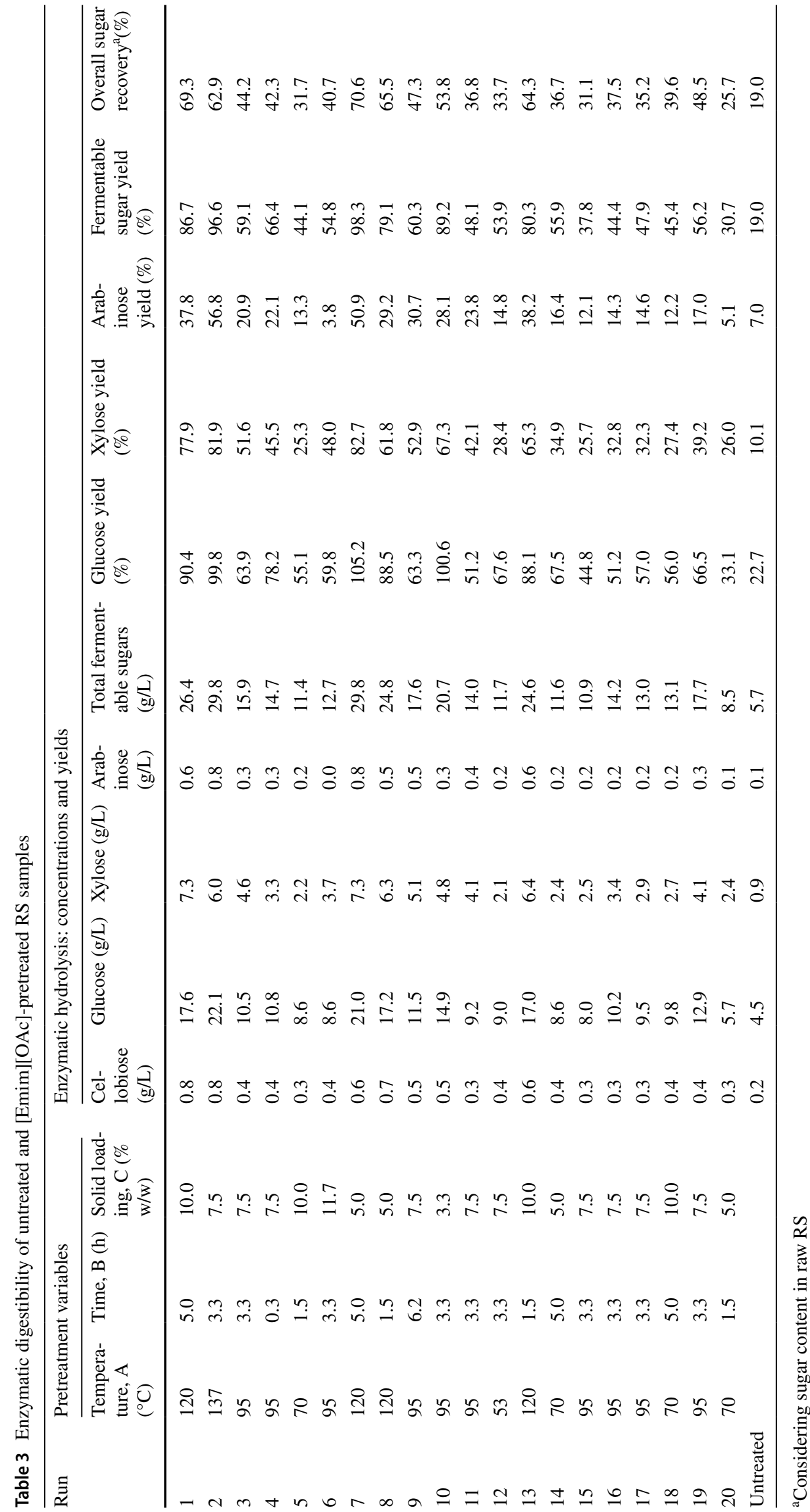


FSY $(\%)=135.0-1.51 \cdot$ Temperature $+1.9 \cdot$ time $-12.35 \cdot$ Solid loading $+0.01274 \cdot$ Temperature $^{2}+1.224$

$\cdot$ time $^{2}+1.091 \cdot$ Solid Loading ${ }^{2}-0.0026 \cdot$ Temperature $\cdot$ time $-0.0265 \cdot$ Temperature $\cdot$ Solid loading -1.045

$\cdot$ time $\cdot$ Solid loading

The analysis of variance results and the coded regression coefficients for the second-order model calculated are shown in Table 4. The ANOVA results indicate that the model was statistically significant $(p<0.05)$ under $95 \%$ of confidence level, whereas lack of fit was insignificant relative to the pure error, indicating the goodness of the fitted regression. Furthermore, the correlation coefficient $\left(R^{2}\right)$ was approximately $84 \%$, which implied that a $16 \%$ of the total variability could not be explained by the regression model. The good correlation between the calculated and experimental values can be seen in Fig. S1 (Supplementary Material). The value of adjusted $R^{2}$ of $70 \%$ and the standard deviation of $11 \%$ also suggested that the model adequately predicted the response. Considering ANOVA results, the linear coefficient of temperature $(A)$ and the quadratic coefficients of temperature $\left(A^{2}\right)$ and solid loading $\left(C^{2}\right)$ were found to be significant for FSY. Based on the fitted quadratic model proposed, three-dimensional response surface plots were generated to examine the interactive effects between any two process pretreatment variables on the response (Fig. 1a-b). As illustrated in Fig. 1, the response surface plots indicate that temperature was the main factor influencing fermentable sugar yield. It can be seen that FSY increased with temperature, regardless of time and solid loading used in the pretreatment process. The higher saccharification yield at higher temperatures could be attributed to several factors. On the one hand, the solubility of lignocellulosic components increases with temperature, resulting in a higher delignification and cellulose dissolution, which is subsequently regenerated in a weaker, more amorphous material and more accessible to enzyme attack. On the other hand, [Emim][OAc] viscosity decreases with increasing temperature, which boosts biomass-IL mixing and mass/heat transfer. In addition to temperature and temperature squared, solid loading squared was also found to be significative for FSY according to the ANOVA test. However, solid loading squared had not as much influence on FSY as the temperature parameters, as reflected in its lower $F$-value and coded coefficient. Solid loading shows to be of importance in achieving high fermentable sugar yields due to the higher efficiency in biomass dissolution, although in terms of overall mass balance, its effect is negligible.

According to the fitted second-order model developed, the values for pretreatment conditions predicted which lead the optimum fermentable sugar yield were $137^{\circ} \mathrm{C}$, $6.2 \mathrm{~h}$, and $3.3 \%(w / w)$ solid loading, which corresponds to the extreme values of the three parameters tested. The statistical model developed showed a limited ability to
Table 4 Analysis of variance (ANOVA) for the quadratic model (fermentable sugar yield)

\begin{tabular}{lllllll}
\hline Source & Sum of squares & $\begin{array}{l}\text { Degrees of } \\
\text { freedom }\end{array}$ & Mean square & F-value & $\begin{array}{l}p \text { value } \\
\text { Prob }>F\end{array}$ & Coefficient $^{\text {a }}$ \\
\hline Model & 6380.64 & 9 & 708.96 & 5.93 & 0.005 & \\
Lineal & 4663.39 & 3 & 1554.46 & 12.99 & 0.001 & 49.10 \\
A, temperature & 4224.92 & 1 & 4224.92 & 35.32 & $<0.0001$ & 17.59 \\
B, time & 128.21 & 1 & 128.21 & 1.07 & 0.325 & 3.06 \\
C, solid loading & 310.26 & 1 & 310.26 & 2.59 & 0.138 & -4.77 \\
Square & 1527.92 & 3 & 509.31 & 4.26 & 0.035 & \\
A $^{2}$ & 914.15 & 1 & 914.15 & 7.64 & 0.0200 & 7.96 \\
B $^{2}$ & 202.43 & 1 & 202.43 & 1.69 & 0.222 & 3.75 \\
$C^{2}$ & 669.46 & 1 & 669.46 & 5.60 & 0.040 & 6.82 \\
2-way interaction & 189.33 & 3 & 63.11 & 0.53 & 0.673 & \\
AB & 0.10 & 1 & 0.10 & 0.00 & 0.977 & -0.11 \\
AC & 21.93 & 1 & 21.93 & 0.18 & 0.678 & -1.66 \\
BC & 167.30 & 1 & 167.30 & 1.40 & 0.264 & -4.57 \\
Residual & 1196.22 & 10 & 119.62 & & & \\
Lack of fit & 893.91 & 5 & 178.78 & 2.96 & 0.130 & \\
Pure error & 302.31 & 5 & 60.46 & & & \\
\hline
\end{tabular}

$R$-squared $=84.21 ;$ Adj. $R$-squared $=70.00 ;$ Std. dev $=10.94 \%$

${ }^{\mathrm{a}}$ For coded values 

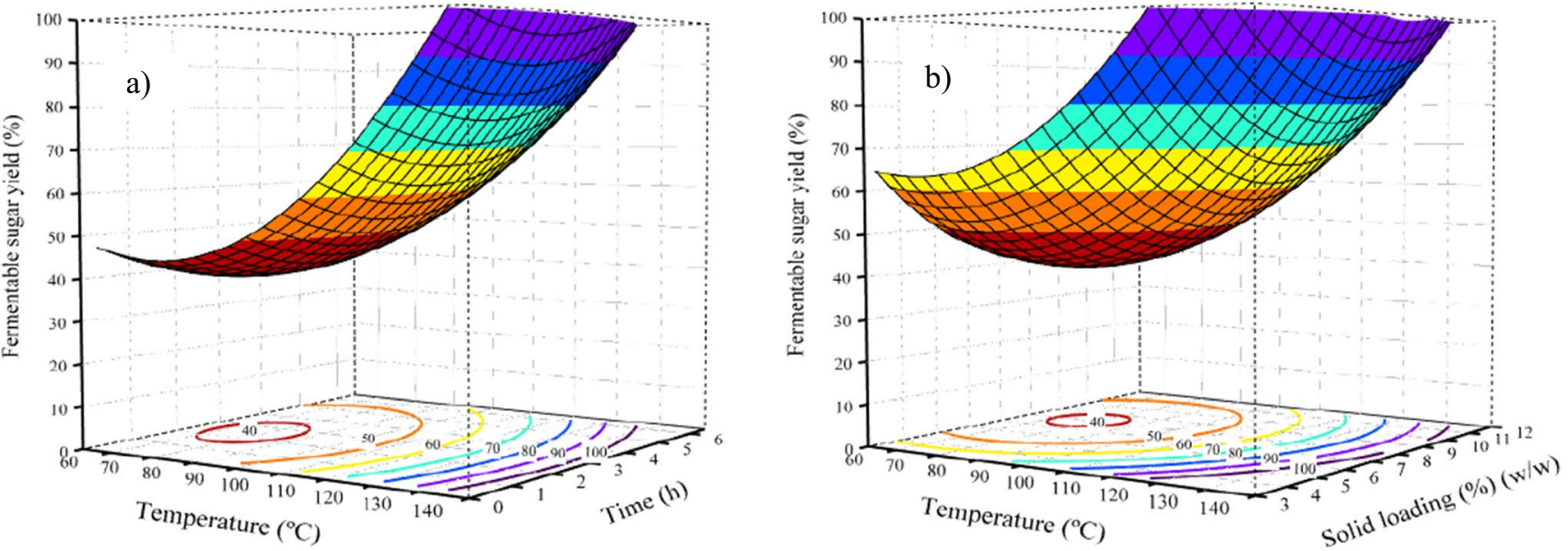

Fig. 1 Three-dimensional response surface plots of the interaction effects of two independent variables on fermentable sugar yield (FSY). The remaining factor was fixed at the center point value: $7.5 \%(w / w)$ (a) and $3.25 \mathrm{~h} \mathrm{(b)}$

predict optimum values as overpredicted the saccharification yield $(161.6 \%)$ as well as overall sugar recovery (99.5\%). To determine the best conditions to enhance enzymatic hydrolysis of RS pretreated with [Emim][OAc], the structural characterizations of the most promising runs ( 2 and 7 ) as well as the worst (run 20) in terms of fermentable sugar yield were carried out in order to additionally consider the effect of [Emim][OAc] on the RS structure for selecting the best operational conditions.

\subsection{Structural characterization}

\subsubsection{FT-IR analysis}

Untreated and [Emim][OAc]-pretreated RS samples (runs 2, 7 , and 20) were characterized by FT-IR to study the structural changes after pretreatment (Fig. 2). The most significant structural changes were appreciated for the spectra from run 7 , while the least modifications were observed in run
Fig. 2 FT-IR spectra of untreated and [Emim][OAc]pretreated rice straw

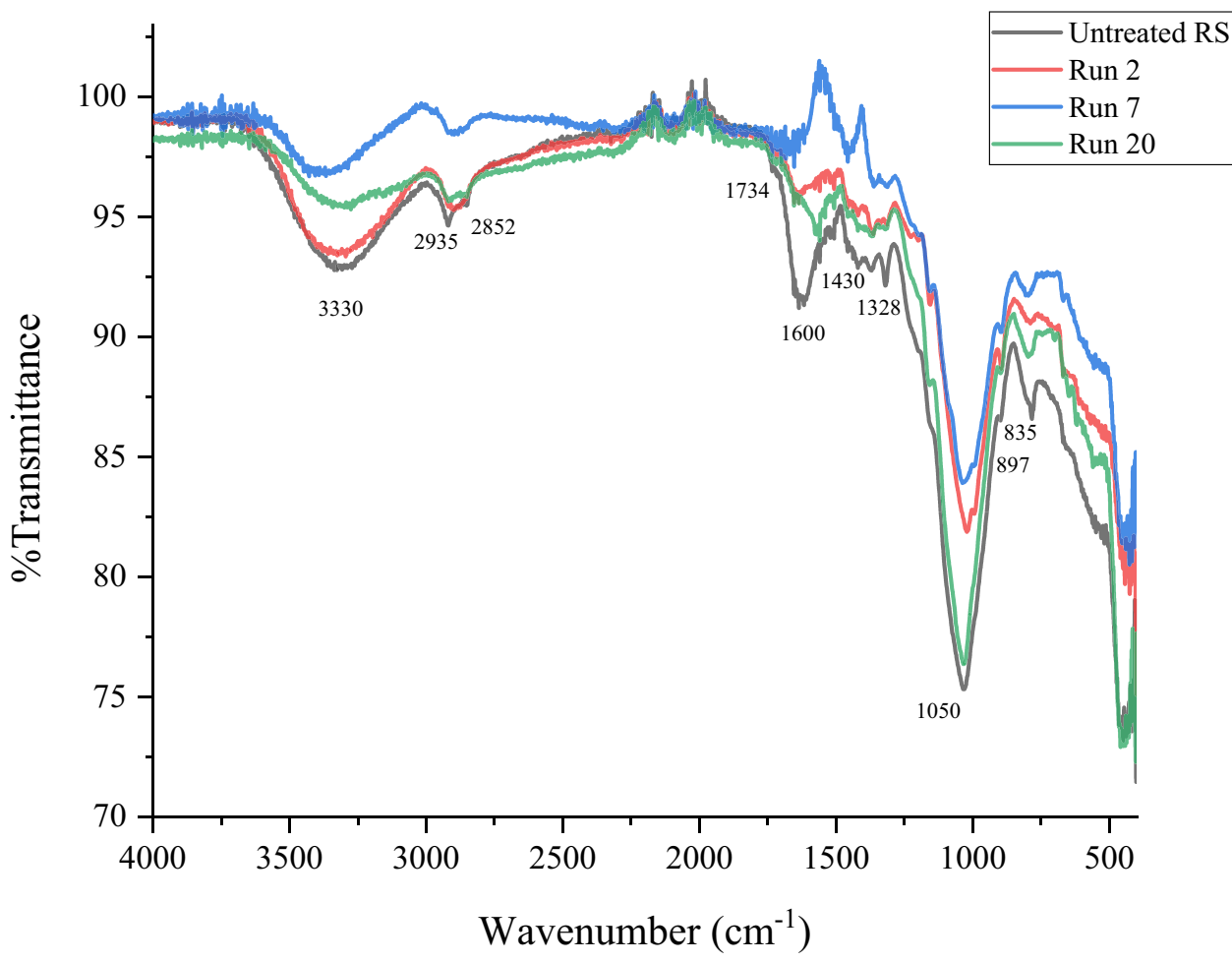


20. The band at $3330 \mathrm{~cm}^{-1}$ representing $\mathrm{OH}$ stretching is displaced to higher intensities in pretreated samples, indicating an increase in the free hydroxyl groups and reduced intermolecular hydrogen bonding [53]. Absorption bands at 1430 and $897 \mathrm{~cm}^{-1}$ represent crystalline cellulose I and amorphous cellulose II, respectively [26, 45]. After pretreatment, the bands at $1430 \mathrm{~cm}^{-1}$ were reduced, while those at $897 \mathrm{~cm}^{-1}$ became more intense, which means that [Emim] [OAc] pretreatment reduces cellulose crystallinity. In pretreated RS samples, band at $1050 \mathrm{~cm}^{-1}$ which is indicative of $\mathrm{C}-\mathrm{O}$ stretching in carbohydrates decreases its intensity, indicating that highly ordered hydrogen bonds in untreated RS have been removed due to cellulose dissolution and regeneration in pretreatment [54]. This dissolution was not significant for pretreatment at $70{ }^{\circ} \mathrm{C}$ (run 20), confirming that this temperature is not high enough to attack RS cellulose. The band at $1734 \mathrm{~cm}^{-1}$, which represents ester bonds linking acetyl and p-coumaryl of hemicellulose and lignin, was also reduced after pretreatment, implying the breaking of ester linkages between these components [53]. Absorption bands at 2852,2925 , and $2935 \mathrm{~cm}^{-1}$ are characteristic of lignin structure, corresponding to symmetric and asymmetric $\mathrm{CH}$ stretching of $\mathrm{CH}_{3}, \mathrm{CH}_{2}$, and $\mathrm{CH}$, softened after pretreatment, probably due to lignin depolymerization by [Emim] [OAc] [55]. The band at $1600 \mathrm{~cm}^{-1}$ (stretching of aromatic benzene ring in lignin) was practically disappeared in pretreated biomass, indicating partial removal of lignin [56]. The bands at 1328 and $835 \mathrm{~cm}^{-1}$ are also associated with lignin, representing syringyl and guaiacyl units [57], which are less intensive in pretreated rice straw indicating again the partial removal of lignin after $[\mathrm{Emim}][\mathrm{OAc}]$ pretreatment, especially at $120^{\circ} \mathrm{C}, 5 \mathrm{~h}$ and $5 \%(\mathrm{w} / \mathrm{w})$ solid loading (run 7), which corresponded to the highest delignification achieved.

\subsubsection{SEM analysis}

Morphological changes on the RS surface after pretreatment were examined by SEM images (Fig. 3). Untreated RS (Fig. 3a-c) presented a highly ordered, packed and inaccessible structure, with well-defined fibers and particulate material on the surface. This particulate material is silica proper of ashes, which restrict enzymatic hydrolysis of sugars [45]. Because of the particle size reduction before pretreatment, raw RS showed mechanical damage in its structure (Fig. 3a) [18]. After [Emim][OAc] pretreatment, no significant changes in morphology were observed in the sample corresponding to run $20\left(70{ }^{\circ} \mathrm{C}, 1.5 \mathrm{~h}, 5 \% \mathrm{w} / \mathrm{w}\right)$ (Fig. $\left.3 \mathrm{~d}-\mathrm{f}\right)$, confirming again that these conditions are not sufficiently severe to disrupt the lignocellulosic matrix. However, this pretreated RS sample showed signs of a slightly disordered structure, although not enough to substantially improve the enzymatic hydrolysis performance. Structural alterations were clearly seen in the samples corresponding at run 2
( $137{ }^{\circ} \mathrm{C}, 3.3 \mathrm{~h}, 7.5 \%$ solid loading) (Fig. $\left.3 \mathrm{j}-1\right)$ and run 7 $\left(120^{\circ} \mathrm{C}, 5 \mathrm{~h}, 5 \%\right.$ solid loading) (Fig. $3 \mathrm{~g}-\mathrm{i}$ ), where the original RS structure was completely lost. In both samples, a disordered and conglomerated structure was observed, which was turned into an amorphous and porous form as a result of [Emim][OAc] pretreatment. Moreover, no fibers were found in these samples, and the particulate material associated with silica and ash was also partially removed, especially in the case of run 7 (Fig. 3g-i). These results indicated that [Emim] [OAc] pretreatment at temperatures up to $120{ }^{\circ} \mathrm{C}$ could reduce RS recalcitrance, leaving a homogeneous structure and an accessible surface area. As a consequence, all sugars were almost completely hydrolyzed in both samples.

\subsubsection{XRD analysis}

X-ray diffraction was used to study changes in crystallinity after [Emim][OAc] pretreatment. XRD patterns of untreated and three pretreated RS samples are shown in Fig. 4. Untreated biomass presents two characteristic cellulose peaks at angles of 15 and $22.1^{\circ}$, corresponding to the (001) and (002) lattice planes of crystalline cellulose I, respectively [58]. Cellulose I is more resistant to cellulase hydrolysis than cellulose II because the van der Waals interactions between hydrogen-bonded layers of cellulose I are stronger than those in cellulose II [59]. After [Emim] [OAc] pretreatment, the maximum peak at $22^{\circ}$ was shifted to a lower angle $\left(\sim 21^{\circ}\right)$, indicating that cellulose I became more amorphous and transited to cellulose II. This alteration commonly occurs in biomass samples pretreated with ILs containing anions that are good hydrogen bond acceptors, as in the case of [Emim][OAc] [42]. The peak at $15^{\circ}$ lost intensity in pretreated samples from runs 2 and 7, suggesting that in these cases, more cellulose had been attacked during [Emim] [OAc] pretreatment. Conversion of cellulose I to cellulose II was also confirmed by calculating the crystallinity index (CrI) of the analyzed samples from XRD data. Untreated RS had a CrI of 50.66\%, indicating a highly crystalline structure. As can be seen in Table 5, the CrI of pretreated samples was reduced in all the cases analyzed in the range of 34-62\%, which directly affected enzymatic hydrolysis yield. A reduced crystallinity index results in a more amorphous cellulose, so that higher saccharification yields were obtained for pretreated RS than untreated samples. The highest crystallinity index reduction $(62.2 \%)$ was obtained in run 7, which had the highest delignification $(64.9 \%)$ as well as the most significant structural changes in RS structure were observed (Fig. 3g-i). In these conditions, the highest saccharification yields were also obtained, confirming the excellent enzymatic susceptibility of this pretreated material. A slightly higher crystallinity index was obtained for run 2 , also showing the good enzymatic susceptibility of 

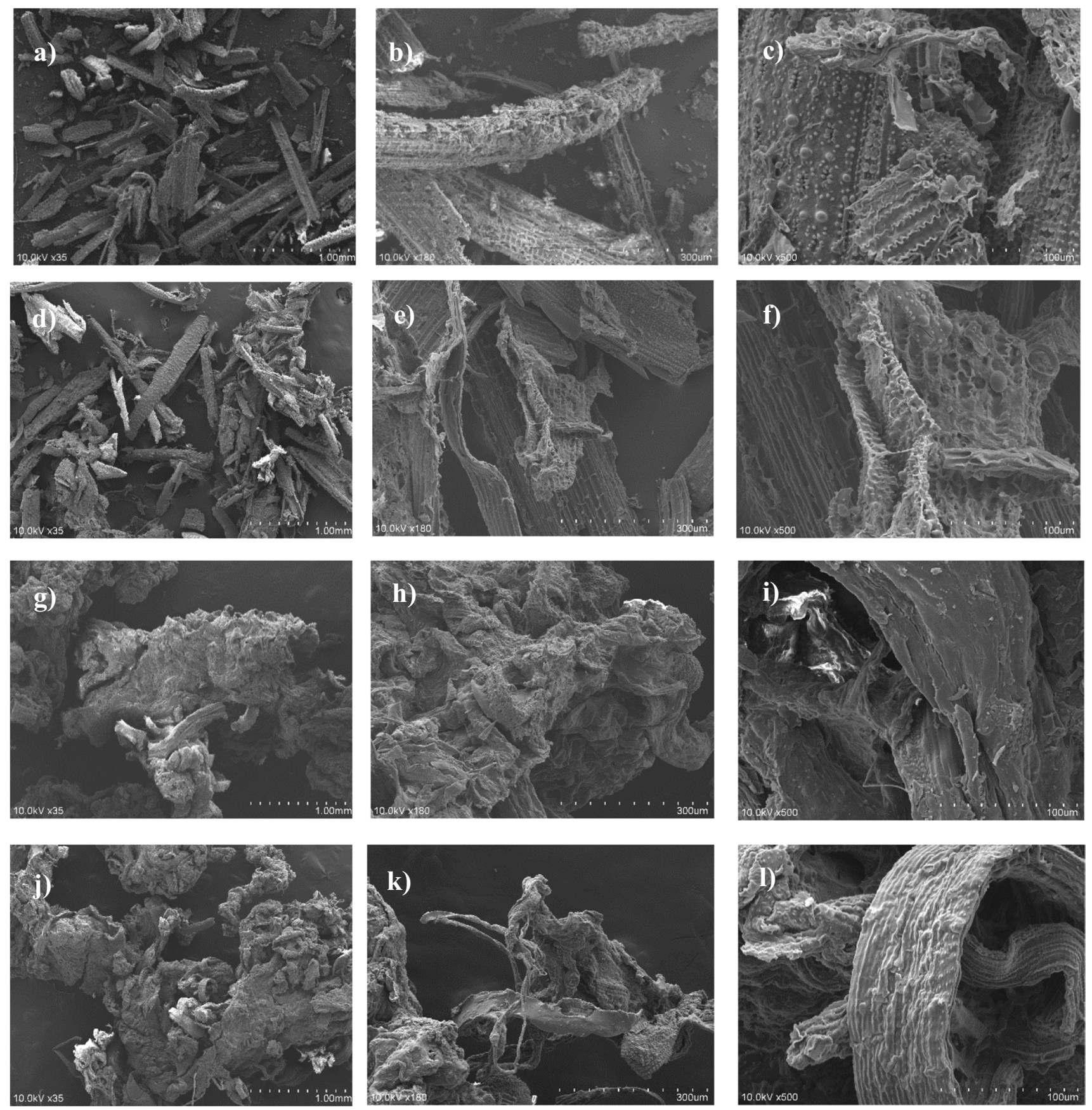

Fig. 3 SEM images of rice straw: a-c untreated RS $(\times 35, \times 180, \times 500), \mathbf{d}-\mathbf{f}$ run $20\left(70{ }^{\circ} \mathrm{C}, 5 \%, 1.5 \mathrm{~h}\right)(\times 35, \times 180, \times 500), \mathbf{g}-\mathbf{i}$ run $7\left(120{ }^{\circ} \mathrm{C}, 5 \%\right.$ solid loading, $5 \mathrm{~h})(\times 35, \times 180, \times 500), \mathbf{j}-\mathbf{l}$ run $2\left(137^{\circ} \mathrm{C}, 7.5 \%\right.$ solid loading, $\left.3.3 \mathrm{~h}\right)(\times 35, \times 180, \times 500)$

this pretreated sample, as reflected in the similar fermentable sugar yield.

\subsection{Selection of pretreatment conditions}

In this work, a mathematical model was developed to optimize the fermentable sugar yield of RS pretreated with $[$ Emim] $[\mathrm{OAc}]$. This model suggested that enzymatic hydrolysis was improved at higher pretreatment temperatures and times and lower solid loadings. To determine the best pretreatment conditions, structural analysis of the most promising runs ( 2 and 7 ) was carried out, revealing no notable differences in RS structure between pretreatment temperatures of $120^{\circ} \mathrm{C}$ (run 7) and $137^{\circ} \mathrm{C}$ (run 2). In fact, delignification and ash losses were higher for the pretreated sample at $120{ }^{\circ} \mathrm{C}$ (run 7). At temperatures up to $120^{\circ} \mathrm{C}$, RS had 
Fig. 4 XRD patterns of untreated and [Emim][OAc]pretreated rice straw

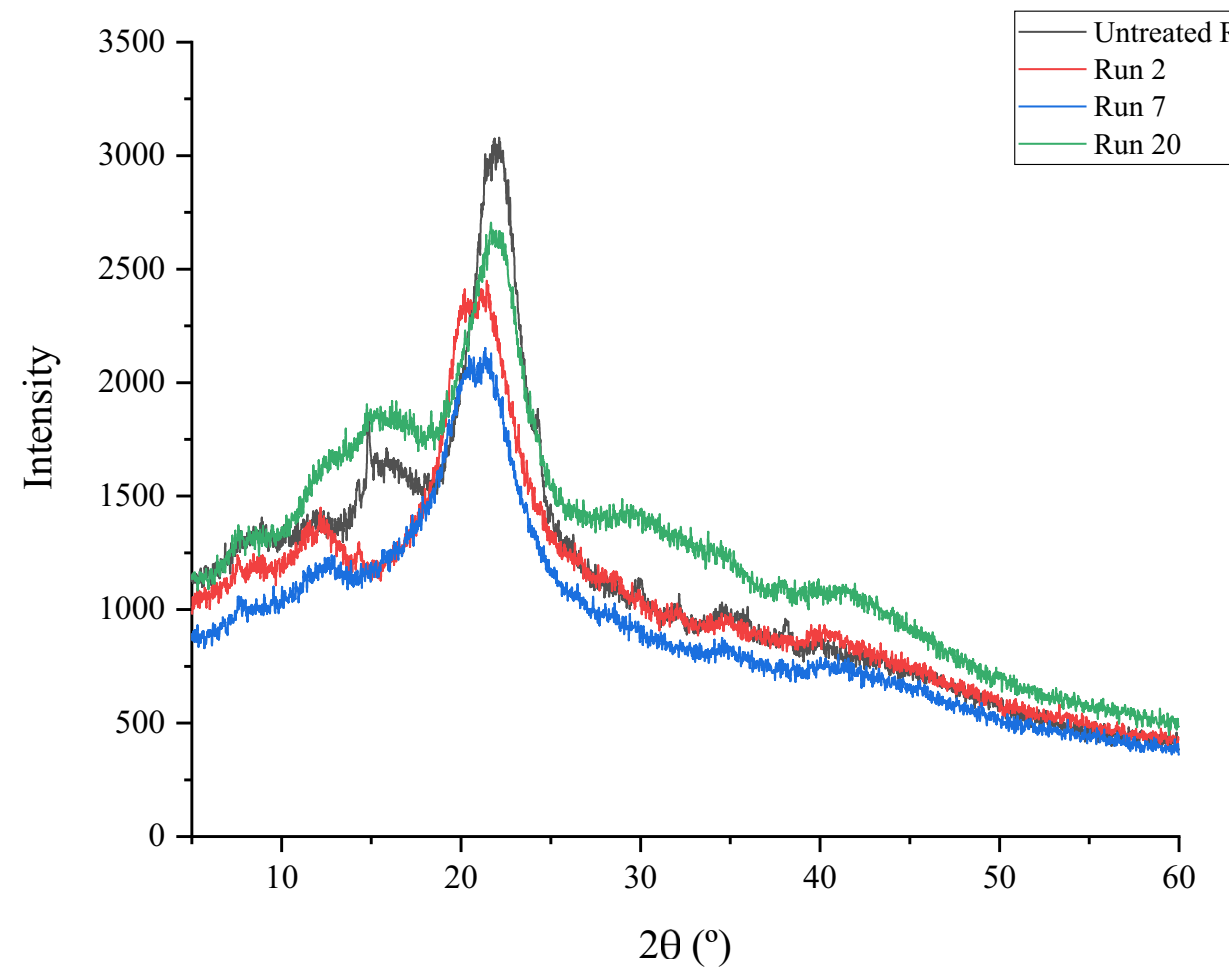

Table 5 Crystallinity index of untreated and [Emim][OAc]-pretreated samples

\begin{tabular}{lllll}
\hline Run & \multicolumn{3}{l}{ Pretreatment conditions } & CrI (\%) \\
\cline { 2 - 4 } & $\mathrm{T}\left({ }^{\circ} \mathrm{C}\right)$ & $t(\mathrm{~h})$ & $\begin{array}{l}\text { Solid loading } \\
(\% \mathrm{w} / \mathrm{w})\end{array}$ \\
\hline Untreated & - & - & - & 50.7 \\
2 & 137 & 3.3 & 7.5 & 23.2 \\
7 & 120 & 5.0 & 5.0 & 19.2 \\
20 & 70 & 1.5 & 5.0 & 33.5 \\
\hline
\end{tabular}

a completely open and easily hydrolysable structure, since practically all the sugars it contained were entirely hydrolyzed. However, at higher temperatures, sugar losses were noticeable, as reflected in overall sugar recovery (Table 3), which should be avoided for the economic viability of the biorefinery process. The evaluation of process losses (overall sugar recovery) and susceptibility of pretreated material (FSY) played an important role in fully analyzing joint pretreatment and enzymatic hydrolysis processes, showing that pretreatment at $120{ }^{\circ} \mathrm{C}$ instead of $137{ }^{\circ} \mathrm{C}$ represented an advantage in terms of RS sugar recovery. Thus, run 7 $\left(120{ }^{\circ} \mathrm{C}, 5 \mathrm{~h}, 5 \%\right.$ solid loading) was selected as the best conditions to RS pretreatment with [Emim][OAc]. At these selected best conditions, fermentable sugar yield was predicted to be $99.2 \%$. Four replicate confirmation experiments were conducted to validate the selected operational parameters. The experimental fermentable sugar yield obtained under the selected conditions was $97.7 \pm 3.3 \%$. Differences of less than $2 \%$ between experimental and predicted values confirmed the soundness of the model prediction.

A comparison of the results obtained with those reported in the literature on similar [Emim][OAc] pretreatment procedures of lignocellulosic substrates is summarized in Table 6 . Among the different operational conditions employed in [Emim][OAc] pretreatment, those used in this work obtained the highest delignification. Regarding enzymatic hydrolysis process, many studies focused only on glucose hydrolysis, neglecting the secondary sugar (xylose), which could be of importance in the context of a biorefinery and sugar exploitation. The glucose hydrolysis yield is higher than $90 \%$ in all the cases analyzed, showing the potential of [Emim] [OAc] in lignocellulosic selective dissolution and the effective attack on crystalline cellulose. Qiu et al. [58] reported a slightly lower glucose yield (87.0\%) due to the shorter time used in [Emim][OAc] pretreatment than the other studies analyzed. Similar glucose yields were obtained in [Emim] [OAc] pretreatment of aspen wood in the best conditions reported in this study [19] as well as in palm oil empty fruit bunch pretreatment at a higher temperature $\left(130{ }^{\circ} \mathrm{C}\right)$ and shorter time (2 h) [60]. Raj et al. [61] concluded that [Emim] [OAc] pretreatment of wheat straw at $10 \%(\mathrm{w} / \mathrm{w})$ solid loading provided better biomass deconstruction at $130{ }^{\circ} \mathrm{C}$ for $2 \mathrm{~h}$ than at $100{ }^{\circ} \mathrm{C}$ for $5 \mathrm{~h}$, confirming that temperature is the main factor affecting the pretreatment process. Although similar glucose yields were obtained in this wheat straw pretreatment than in the present work, lower degrees of 
Table 6 Comparison of [Emim][OAc] pretreatments of different lignocellulosic substrates

\begin{tabular}{|c|c|c|c|c|c|c|c|c|}
\hline \multirow{2}{*}{$\begin{array}{l}\text { Lignocellulosic } \\
\text { substrate }\end{array}$} & \multicolumn{3}{|c|}{ Pretreatment conditions } & \multicolumn{3}{|c|}{ Enzymatic hydrolysis } & \multirow[t]{2}{*}{ Delignification } & \multirow[t]{2}{*}{ Reference } \\
\hline & Temperature & Time & Solid loading & Biomass loading & Enzyme loading & $\begin{array}{l}\text { Hydrolysis yield* } \\
(\%)\end{array}$ & & \\
\hline $\begin{array}{l}\text { Energy cane } \\
\text { bagasse }\end{array}$ & $120^{\circ} \mathrm{C}$ & $30 \mathrm{~min}$ & $5 \%(\mathrm{w} / \mathrm{w})$ & $1 \%(\mathrm{w} / \mathrm{v})$ & $\begin{array}{l}\text { Spezyme CP (30 } \\
\text { FPU/g glucan) } \\
\text { Novozyme } 188 \\
\text { (30 CBU/g } \\
\text { glucan) }\end{array}$ & $\begin{array}{l}87 \% \text { cellulose } \\
\text { yield } \\
64.3 \% \text { hemicel- } \\
\text { lulose yield }\end{array}$ & $32.0(\%)$ & {$[58]$} \\
\hline Aspen wood & $120^{\circ} \mathrm{C}$ & $5 \mathrm{~h}$ & $5 \%(\mathrm{w} / \mathrm{w})$ & $3 \%(\mathrm{w} / \mathrm{v})$ & $\begin{array}{l}\text { Celluclast } 1.5 \mathrm{~L} \\
\text { (20 FPU/g } \\
\text { glucan) } \\
\text { Novozyme } 188 \\
\text { (30 CBU/g } \\
\text { glucan) }\end{array}$ & $\begin{array}{l}95.4 \% \text { glucose } \\
\text { yield }\end{array}$ & $* *$ & [19] \\
\hline $\begin{array}{l}\text { Oil palm empty } \\
\text { fruit bunch }\end{array}$ & $130^{\circ} \mathrm{C}$ & $2 \mathrm{~h}$ & $5 \%(\mathrm{w} / \mathrm{w})$ & $5 \%(w / v)$ & $\begin{array}{l}\text { Celluclast } 1.5 \mathrm{~L} \\
(30 \mathrm{FPU} / \mathrm{g} \\
\text { glucan) } \\
\text { Novozyme } 188 \\
(1 / 3(v / \mathrm{v}) \text { of } \\
\text { Celluclast } \\
1.5 \mathrm{~L})\end{array}$ & $\begin{array}{l}95.5 \% \text { glucose } \\
\text { yield }\end{array}$ & $52.6(\%)$ & {$[60]$} \\
\hline Wheat straw & $130{ }^{\circ} \mathrm{C}$ & $2 \mathrm{~h}$ & $10 \%(w / w)$ & $10 \%(w / w)$ & $\begin{array}{l}\text { SacchariSEBC6 } \\
\text { (10 FPU/g } \\
\text { biomass) }\end{array}$ & $\begin{array}{l}98.7 \% \text { glucose } \\
\text { yield } \\
42 \% \text { xylose yield }\end{array}$ & $51.0(\%)$ & {$[61]$} \\
\hline Rice straw & $120^{\circ} \mathrm{C}$ & $5 \mathrm{~h}$ & $5 \%(w / w)$ & $5 \%(\mathrm{w} / \mathrm{v})$ & $\begin{array}{l}\text { Cellic Ctec } 2 \\
(20 \mathrm{FPU} / \mathrm{g} \text { bio- } \\
\text { mass })\end{array}$ & $\begin{array}{l}100 \% \text { glucose } \\
\text { yield } \\
82 \% \text { xylose yield }\end{array}$ & $65.0(\%)$ & This study \\
\hline
\end{tabular}

*Calculated based on total glucose/xylose present in pretreated biomass

**Not indicated

delignification and xylose yield were achieved than ours. In this regard, the higher solid loading $(10 \%(\mathrm{w} / \mathrm{w}))$ used in wheat straw pretreatment could make lignin extraction difficult, while the higher temperature $\left(130^{\circ} \mathrm{C}\right)$ could promote xylose degradation. Despite the excellent enhancement in enzymatic hydrolysis of biomass after pretreatment with [Emim][OAc], conventional pretreatment methods still represent a cheaper alternative and easy to operate process than IL pretreatments. In this context, microwave-assisted hydrothermolysis of RS at high temperature $\left(200{ }^{\circ} \mathrm{C}\right)$ resulted in a poor delignification (13\%) and a relative low enzymatic hydrolysis yield $(<50 \%)$ as demonstrated by Valles et al. [62]. Similar delignification degree as obtained in this study (64\%) was reported in organosolv pretreatment of RS using ethanol and sulfuric acid as catalyst at $180^{\circ} \mathrm{C}$ during $30 \mathrm{~min}$ with $12.5 \%$ w/w solid loading [63], although notable lower enzymatic hydrolysis yields $(<50 \%)$ were achieved. Higher saccharification yields $(85 \%$ and $67 \%$ of glucose and xylose yield, respectively) were reported in RS alkaline pretreatment, consisting in $\mathrm{NaOH} 0.75 \%(w / v)$ at $134{ }^{\circ} \mathrm{C}$ for $20 \mathrm{~min}$ at $5 \%(\mathrm{w} / \mathrm{w})$ solid loading [48], although not as high promising as those reported herein. Although this pretreatment is demonstrated to be more effective than some of the most common used, further investigation is necessary in order to develop the industrial process focusing in using higher solid loadings and lower times as well as in the recycling of the IL, making it possible for the process to be economically viable.

\section{Conclusions}

The feasibility of using [Emim][OAc] in rice straw pretreatment was proved in this work, obtaining enhanced biomass digestibility. Structural analysis has been shown as a very useful tool for the better assessment of enzymatic hydrolysis. The best processing conditions selected for [Emim] [OAc] pretreatment of RS were determined to be $120{ }^{\circ} \mathrm{C}, 5 \mathrm{~h}, 5 \%(\mathrm{w} / \mathrm{w})$. Under these conditions, nearly all the sugars in pretreated RS were hydrolyzed, whereas the highest delignification (65\%) and the most significant structural changes in RS were obtained, showing the suitability of [Emim][OAc] for RS pretreatment. Due to this [Emim][OAc] potential in the biorefinery context, further studies on the recovery and reutilization of this IL should be carried out in order to study the cost-effectiveness of pretreatment process. 
Supplementary Information The online version contains supplementary material available at https://doi.org/10.1007/s13399-021-02111-7.

Author contribution Helena Poy, investigation, formal analysis, writing - original draft, and visualization. Estela Lladosa, conceptualization, methodology, investigation, writing - review and editing, and supervision. Carmen Gabaldón, conceptualization, methodology, investigation, writing - review and editing, supervision, project administration, and funding acquisition. Sonia Loras, conceptualization, methodology, writing - review and editing, resources, and funding acquisition.

Funding Open Access funding provided thanks to the CRUE-CSIC agreement with Springer Nature. Financial support was obtained from the FEDER/Ministerio de Ciencia e Innovación - Agencia Estatal de Investigación/Project CTM2017-88042-R (Spain), Conselleria d'Innovació, Universitats, Ciència i Societat Digital/Project GV/2019/155 and Project AICO/2021/121 (Generalitat Valenciana, Spain). In addition, Helena Poy received $\mathrm{PhD}$ fellowship (FPU18/02817) from the Ministerio de Educación y Ciencia (Spain).

Data availability Not applicable.

Code availability Minitab (version 19) and Origin (version 2021).

\section{Declarations}

Ethics approval Not applicable.

Consent to participate Not applicable.

Consent for publication Not applicable.

Conflict of interest The authors declare no competing interests.

Open Access This article is licensed under a Creative Commons Attribution 4.0 International License, which permits use, sharing, adaptation, distribution and reproduction in any medium or format, as long as you give appropriate credit to the original author(s) and the source, provide a link to the Creative Commons licence, and indicate if changes were made. The images or other third party material in this article are included in the article's Creative Commons licence, unless indicated otherwise in a credit line to the material. If material is not included in the article's Creative Commons licence and your intended use is not permitted by statutory regulation or exceeds the permitted use, you will need to obtain permission directly from the copyright holder. To view a copy of this licence, visit http://creativecommons.org/licenses/by/4.0/.

\section{References}

1. Raghavi S, Sindhu R, Binod P et al (2016) Development of a novel sequential pretreatment strategy for the production of bioethanol from sugarcane trash. Bioresour Technol 199:202-210. https:// doi.org/10.1016/j.biortech.2015.08.062

2. Mathew AK, Abraham A, Mallapureddy KK, Sukumaran RK (2018) Lignocellulosic biorefinery wastes, or resources? In: Waste biorefinery: potential and perspectives. Elsevier B.V., pp 267-297

3. Jafari Y, Amiri H, Karimi K (2016) Acetone pretreatment for improvement of acetone, butanol, and ethanol production from sweet sorghum bagasse. Appl Energy 168:216-225. https://doi. org/10.1016/j.apenergy.2016.01.090

4. Harun S, Balan V, Takriff MS et al (2013) Performance of AFEX ${ }^{\mathrm{TM}}$ pretreated rice straw as source of fermentable sugars: the influence of particle size. Biotechnol Biofuels 6:1-17. https:// doi.org/10.1186/1754-6834-6-40

5. Cunha R, Castro DA, Guedes B, Túlio H (2017) Alkaline deacetylation as a strategy to improve sugars recovery and ethanol production from rice straw hemicellulose and cellulose. 106:65-73. https://doi.org/10.1016/j.indcrop.2016.08.053

6. Karimi K, Kheradmandinia S, Taherzadeh MJ (2006) Conversion of rice straw to sugars by dilute-acid hydrolysis. Biomass Bioenergy 30:247-253. https://doi.org/10.1016/j.biombioe.2005.11.015

7. Zhu S, Wu Y, Yu Z et al (2005) Pretreatment by microwave/ alkali of rice straw and its enzymic hydrolysis. Process Biochem 40:3082-3086. https://doi.org/10.1016/j.procbio.2005.03.016

8. Hendriks ATWM, Zeeman G (2009) Pretreatments to enhance the digestibility of lignocellulosic biomass. Bioresour Technol 100:10-18. https://doi.org/10.1016/j.biortech.2008.05.027

9. Nargotra P, Sharma V, Gupta M et al (2018) Application of ionic liquid and alkali pretreatment for enhancing saccharification of sunflower stalk biomass for potential biofuel-ethanol production. Bioresour Technol 267:560-568. https://doi.org/10.1016/j. biortech.2018.07.070

10. Usmani Z, Sharma M, Gupta P et al (2020) Ionic liquid based pretreatment of lignocellulosic biomass for enhanced bioconversion. Bioresour Technol 304:123003. https://doi.org/10.1016/j. biortech.2020.123003

11. Halder P, Kundu S, Patel S et al (2019) Progress on the pretreatment of lignocellulosic biomass employing ionic liquids. Renew Sust Energ Rev 105:268-292. https://doi.org/10.1016/j. rser.2019.01.052

12. Mai NL, Ha SH, Koo YM (2014) Efficient pretreatment of lignocellulose in ionic liquids/co-solvent for enzymatic hydrolysis enhancement into fermentable sugars. Process Biochem 49:1144-1151. https://doi.org/10.1016/j.procbio.2014.03.024

13. Behera S, Arora R, Nandhagopal N, Kumar S (2014) Importance of chemical pretreatment for bioconversion of lignocellulosic biomass. Renew Sust Energ Rev 36:91-106. https://doi.org/10. 1016/j.rser.2014.04.047

14. Zhu S, Wu Y, Chen Q et al (2006) Dissolution of cellulose with ionic liquids and its application: a mini-review. Green Chem 8:325-327. https://doi.org/10.1039/b601395c

15. Dadi AP, Varanasi S, Schall CA (2006) Enhancement of cellulose saccharification kinetics using an ionic liquid pretreatment step. Biotechnol Bioeng 95:904-910. https://doi.org/10.1002/ bit. 21047

16. Mäki-Arvela P, Anugwom I, Virtanen P et al (2010) Dissolution of lignocellulosic materials and its constituents using ionic liquids-a review. Ind Crop Prod 32:175-201. https://doi.org/10.1016/j.inder op.2010.04.005

17. Odorico FH, de Morandim-Giannetti AA, Lucarini AC, Torres RB (2018) Pretreatment of Guinea grass (Panicum maximum) with the ionic liquid 1-ethyl-3-methyl imidazolium acetate for efficient hydrolysis and bioethanol production. Cellulose 25:2997-3009. https://doi.org/10.1007/s10570-018-1753-z

18. Equihua-Sánchez M, Barahona-Pérez LF (2019) Physical and chemical characterization of Agave tequilana bagasse pretreated with the ionic liquid 1-ethyl-3-methylimidazolium acetate. Waste and Biomass Valorization 10:1285-1294. https://doi.org/10.1007/ s12649-017-0150-4

19. Goshadrou A, Karimi K, Lefsrud M (2013) Characterization of ionic liquid pretreated aspen wood using semi-quantitative methods for ethanol production. Carbohydr Polym 96:440-449. https:// doi.org/10.1016/j.carbpol.2013.04.017 
20. Barr CJ, Mertens JA, Schall CA (2012) Critical cellulase and hemicellulase activities for hydrolysis of ionic liquid pretreated biomass. Bioresour Technol 104:480-485. https://doi.org/10. 1016/j.biortech.2011.10.101

21. Haykir NI, Bakir U (2013) Ionic liquid pretreatment allows utilization of high substrate loadings in enzymatic hydrolysis of biomass to produce ethanol from cotton stalks. Ind Crop Prod 51:408-414. https://doi.org/10.1016/j.indcrop.2013.10.017

22. Ferreira S, Duarte AP, Ribeiro MHL et al (2009) Response surface optimization of enzymatic hydrolysis of Cistus ladanifer and Cytisus striatus for bioethanol production. Biochem Eng $\mathrm{J}$ 45:192-200. https://doi.org/10.1016/j.bej.2009.03.012

23. Tan HT, Lee KT, Mohamed AR (2011) Pretreatment of lignocellulosic palm biomass using a solvent-ionic liquid [BMIM]cl for glucose recovery: an optimisation study using response surface methodology. Carbohydr Polym 83:1862-1868. https://doi.org/ 10.1016/j.carbpol.2010.10.052

24. Trinh LTP, Lee Y-J, Lee J-W, Lee W-H (2018) Optimization of ionic liquid pretreatment of mixed softwood by response surface methodology and reutilization of ionic liquid from hydrolysate. Biotechnol Bioprocess Eng 23:228-237. https://doi.org/10.1007/ s12257-017-0209-x

25. Wang S, You T, Xu F et al (2015) Optimization of [Amim]cl pretreatment conditions for maximum glucose recovery from hybrid Pennisetum by response surface methodology. BioResources 10:7021-7037. https://doi.org/10.15376/biores.10.4.7021-7037

26. Yoon LW, Ang TN, Ngoh GC, Chua ASM (2012) Regression analysis on ionic liquid pretreatment of sugarcane bagasse and assessment of structural changes. Biomass Bioenergy 36:160-169. https://doi.org/10.1016/j.biombioe.2011.10.033

27. Fu D, Mazza G (2011) Optimization of processing conditions for the pretreatment of wheat straw using aqueous ionic liquid. Bioresour Technol 102:8003-8010. https://doi.org/10.1016/j.biort ech.2011.06.023

28. Adney B, Baker J (1996) Measurement of cellulase activities: laboratory analytical procedure (LAP). National Renewable Energy Laboratory, Golden

29. Sluiter J, Sluiter A (2011) Summative mass closure: laboratory analytical procedure (LAP). Golden

30. Sluiter A, Hames B, Hyman D, et al (2008) Determination of total solids in biomass and total dissolved solids in liquid process samples laboratory analytical procedure (LAP) Issue Date: 3/31/2008

31. Sluiter A, Hames B, Ruiz R, et al (2005) Determination of ash in biomass: laboratory analytical procedure (LAP). Golden

32. A. Sluiter, R. Ruiz, C. Scarlata, J. Sluiter A, Templeton D (2008) Determination of extractives in biomass: laboratory analytical procedure (LAP); Issue Date 7/17/2005-42619.pdf. Tech Rep NREL/ TP-510-42619 1-9

33. Sluiter A, Hames B, Ruiz R, et al (2008) Determination of structural carbohydrates and lignin in biomass: laboratory analytical procedure (LAP). Golden

34. Segal L, Creely JJ, Martin AE, Conrad CM (1959) An empirical method for estimating the degree of crystallinity of native cellulose using the X-ray diffractometer. Text Res J 29:786-794. https://doi.org/10.1177/004051755902901003

35. Doan HT, Nguyen PTM, Tran TT et al (2021) Optimizing lime pretreatment of rice straw for biolipid production using oleaginous microorganisms. Chemosphere 269:129390. https://doi.org/ 10.1016/j.chemosphere.2020.129390

36. Sun J, Shi J, Murthy Konda NVSN et al (2017) Efficient dehydration and recovery of ionic liquid after lignocellulosic processing using pervaporation. Biotechnol Biofuels 1:1-14. https://doi.org/ 10.1186/s13068-017-0842-9

37. Li C, Tanjore D, He W et al (2013) Scale-up and evaluation of high solid ionic liquid pretreatment and enzymatic hydrolysis of switchgrass. Biotechnol Biofuels 6:1-13. https://doi.org/10.1186/ 1754-6834-6-154

38. Lee SH, Doherty TV, Linhardt RJ, Dordick JS (2009) Ionic liquid-mediated selective extraction of lignin from wood leading to enhanced enzymatic cellulose hydrolysis. Biotechnol Bioeng 102:1368-1376. https://doi.org/10.1002/bit.22179

39. Li W, Sun N, Stoner B et al (2011) Rapid dissolution of lignocellulosic biomass in ionic liquids using temperatures above the glass transition of lignin. Green Chem 13:2038-2047. https://doi.org/ $10.1039 / \mathrm{c} 1 \mathrm{gc} 15522 \mathrm{a}$

40. Tan HT, Lee KT (2012) Understanding the impact of ionic liquid pretreatment on biomass and enzymatic hydrolysis. Chem Eng J 183:448-458. https://doi.org/10.1016/j.cej.2011.12.086

41. Weerachanchai P, Leong SSJ, Chang MW et al (2012) Improvement of biomass properties by pretreatment with ionic liquids for bioconversion process. Bioresour Technol 111:453-459. https:// doi.org/10.1016/j.biortech.2012.02.023

42. Fockink DH, Andreaus J, Ramos LP, Łukasik RM (2020) Pretreatment of cotton spinning residues for optimal enzymatic hydrolysis: a case study using green solvents. Renew Energy 145:490 499. https://doi.org/10.1016/j.renene.2019.06.042

43. van der Veen M, Stuart MC, Norde W (2007) Spreading of proteins and its effect on adsorption and desorption kinetics. Colloids Surfaces B Biointerfaces 54:136-142. https://doi.org/10.1016/j. colsurfb.2006.08.017

44. Talukder MMR, Goh HY, Puah SM (2017) Interaction of silica with cellulase and minimization of its inhibitory effect on cellulose hydrolysis. Biochem Eng J 118:91-96. https://doi.org/10. 1016/j.bej.2016.11.016

45. Poornejad N, Karimi K, Behzad T (2014) Ionic liquid pretreatment of rice straw to enhance saccharification and bioethanol production. J Biomass to Biofuel. https://doi.org/10.11159/jbb.2014. 002

46. Liu Y, Geng Y, Zhou Q, Yuan W (2018) The effect of furfural and 5-hydroxymethyl furfural on butyric acid fermentation by clostridium tyrobutyricum. J Chem Technol Biotechnol 93:849854. https://doi.org/10.1002/jctb.5439

47. Liu H, Zhang J, Yuan J et al (2019) Omics-based analyses revealed metabolic responses of clostridium acetobutylicum to lignocellulose-derived inhibitors furfural, formic acid and phenol stress for butanol fermentation. Biotechnol Biofuels 12:1-20. https://doi. org/10.1186/s13068-019-1440-9

48. Valles A, Capilla M, Álvarez-Hornos FJ et al (2021) Optimization of alkali pretreatment to enhance rice straw conversion to butanol. Biomass Bioenergy 150:106131. https://doi.org/10.1016/j.biomb ioe.2021.106131

49. Wang $\mathrm{S}$, Zhang $\mathrm{Y}$, Dong $\mathrm{H}$ et al (2011) Formic acid triggers the "acid crash" of acetone-butanol-ethanol fermentation by clostridium acetobutylicum. Appl Environ Microbiol 77:1674-1680. https://doi.org/10.1128/AEM.01835-10

50. Bellido C, Infante C, Coca M et al (2015) Efficient acetonebutanol-ethanol production by Clostridium beijerinckii from sugar beet pulp. Bioresour Technol 190:332-338. https://doi.org/ 10.1016/j.biortech.2015.04.082

51. Jönsson LJ, Martín C (2016) Pretreatment of lignocellulose: formation of inhibitory by-products and strategies for minimizing their effects. Bioresour Technol 199:103-112. https://doi.org/10. 1016/j.biortech.2015.10.009

52. Ninomiya K, Ogino C, Ishizaki M et al (2015) Effect of post-pretreatment washing on saccharification and co-fermentation from bagasse pretreated with biocompatible cholinium ionic liquid. Biochem Eng J 103:198-204. https://doi.org/10.1016/j.bej.2015. 08.002

53. Nasirpour N, Mousavi SM (2018) RSM based optimization of PEG assisted ionic liquid pretreatment of sugarcane bagasse for 
enhanced bioethanol production: effect of process parameters. Biomass Bioenergy 116:89-98. https://doi.org/10.1016/j.biomb ioe. 2018.06 .008

54. Shi J, Balamurugan K, Parthasarathi R et al (2014) Understanding the role of water during ionic liquid pretreatment of lignocellulose: co-solvent or anti-solvent? Green Chem 16:3830-3840. https://doi.org/10.1039/c4gc00373j

55. da Costa Lopes AM, João KG, Rubik DF et al (2013) Pre-treatment of lignocellulosic biomass using ionic liquids: wheat straw fractionation. Bioresour Technol 142:198-208. https://doi.org/10. 1016/j.biortech.2013.05.032

56. Srisampao I, Rodiahwati W, Pornwongthong P, et al (2018) Pretreatment optimization of cholinium ionic liquid for maximizing sugar release from rice straw. ACM Int Conf Proceeding Ser 169-173. https://doi.org/10.1145/3208854.3208864

57. Saha K, Dasgupta J, Chakraborty S et al (2017) Optimization of lignin recovery from sugarcane bagasse using ionic liquid aided pretreatment. Cellulose 24:3191-3207. https://doi.org/10.1007/ s10570-017-1330-x

58. Qiu Z, Aita GM, Walker MS (2012) Effect of ionic liquid pretreatment on the chemical composition, structure and enzymatic hydrolysis of energy cane bagasse. Bioresour Technol 117:251256. https://doi.org/10.1016/j.biortech.2012.04.070

59. Cheng G, Varanasi P, Li C et al (2011) Transition of cellulose crystalline structure and surface morphology of biomass as a function of ionic liquid pretreatment and its relation to enzymatic hydrolysis. Biomacromolecules 12:933-941. https://doi.org/10. 1021/bm101240z

60. Katinonkul W, Lee JS, Ha SH, Park JY (2012) Enhancement of enzymatic digestibility of oil palm empty fruit bunch by ionicliquid pretreatment. Energy 47:11-16. https://doi.org/10.1016/j. energy.2012.06.050

61. Raj T, Gaur R, Dixit P et al (2016) Ionic liquid pretreatment of biomass for sugars production: driving factors with a plausible mechanism for higher enzymatic digestibility. Carbohydr Polym 149:369-381. https://doi.org/10.1016/j.carbpol.2016.04.129

62. Valles A, Álvarez-Hornos FJ, Martínez-Soria V et al (2020) Comparison of simultaneous saccharification and fermentation and separate hydrolysis and fermentation processes for butanol production from rice straw. Fuel 282:118831. https://doi.org/10. 1016/j.fuel.2020.118831

63. Amiri H, Karimi K, Zilouei H (2014) Organosolv pretreatment of rice straw for efficient acetone, butanol, and ethanol production. Bioresour Technol 152:450-456. https://doi.org/10.1016/j.biort ech.2013.11.038

Publisher's note Springer Nature remains neutral with regard to jurisdictional claims in published maps and institutional affiliations. 